\title{
Efficacy and safety of ondansetron in preventing postanesthesia shivering: a meta-analysis of randomized controlled trials
}

\author{
Hong-Tao Tie ${ }^{1 \dagger}$, Guang-Zhu Su${ }^{2 *+}$, Kun He${ }^{2}$, Shao-Rong Liang ${ }^{2}$, Hao-Wei Yuan ${ }^{1}$ and Jun-Huan Mou ${ }^{1}$
}

\begin{abstract}
Background: Shivering is a very common complication in the postanesthesia period. Increasing studies have reported ondansetron may be effective in prevention of postanesthesia shivering (PAS). However, the results remained controversial; hence we conducted a meta-analysis of randomized controlled trials to evaluate the efficacy and safety of ondansetron on the prevention of postanesthesia shivering.

Methods: PubMed and Embase databases were searched to identify the eligible randomized controlled trials assessing the effect of ondansetron on the prevention of PAS. Results were expressed as risk ratios (RRs) with accompanying 95\% confidence intervals $(\mathrm{Cls})$. The meta-analysis was performed with fixed-effect model or random-effect model according to the heterogeneity.

Results: Six trials including 533 subjects were included. Compared with placebo, ondansetron was associated with a significant reduction of PAS (RR 0.43,95\% Cl, 0.27-0.70), without an increased risk of bradycardia (RR 0.37, 95\% Cl, 0.12-1.15). Compared with meperidine, no difference was observed in the incidence of PAS (RR $0.68,95 \% \mathrm{Cl}, 0.39-1.19$ ) and bradycardia (RR 2.0, 95\% Cl, 0.38-10.64).
\end{abstract}

Conclusions: Ondansetron has a preventive effect on PAS without a paralleled side effect of bradycardia.

Keywords: Qndansetron, Postanesthesia shivering, Meta-analysis

\section{Background}

Shivering, a very common complication of surgery owing to postoperative pain and postanesthesia hypothermia, is distressing for both patients and clinicians [1]. It can be defined as involuntary and oscillatory muscular activities that increase the metabolic rate by two to three folds to maintain the core temperature, with the increment of heat production by only $200 \%$ in adults [2]. Both neuraxial (epidural and spinal anesthesia) and general anesthesia are associated with a significant incidence of shivering, and the incidence is $40 \%-60 \%$ in regional anesthetic patients [3] and up to $60 \%$ in general anesthetic ones [4]. Shivering can be associated with severe adverse effects by increasing the oxygen consumption and carbon dioxide retention. It can cause arterial hypoxia, increase cardiac output and the

\footnotetext{
* Correspondence: suguangzhu@163.com

${ }^{\dagger}$ Equal contributors

Department of Pharmacy, Jinan Central Hospital, Jinan 250013, Shandong, China Full list of author information is available at the end of the article
}

risk of myocardial ischemia. Besides, the movement of shivering interferes with the electrocardiogram, blood pressure, and pulse oximetry [5].

Recent years, with increasing awareness of its undesirable aftermath, effective prevention of postanesthesia shivering (PAS) is being imperative. It has been reported that PAS could be prevented by warming skin-surface [6] and warming the administered fluid $[7,8]$, but it is not a perfect way. Many drugs have been shown to be effective on prevention of PAS, such as opioids, $\alpha 2$-agonist, anticholinergic, CNS stimulant, corticosteroid [9], however, few of them were recommended for the prevention of PAS due to various side-effects. For instance, Clonidine, a partial $\alpha 2$ adrenergic agonist, is related to bradycardia, hypotension and sedation [10].

Ondansetron, a 5-TH3 receptor antagonist, is widely used to prevent postoperative and pregnancy nausea and vomiting. 5-TH can affect the body temperature and shivering in rats since the balance of nor-epinephrine 
and 5-hydroxytryptamine $(5-\mathrm{HT})$ in the preoptic-anterior hypothalamus controls the temperature set point $[11,12]$. Consistently, several studies [3,13-16] have demonstrated ondansetron can prevent PAS, which made ondansetron a promising drug for postoperative complications including PAS, nausea and vomiting. However, a later-day, largesample study conducted by Browning et al. [17] presented that ondansetron did not prevent PAS among women undergoing combined spinal and epidural anesthesia for cesarean delivery. To our knowledge, there is no metaanalysis to identify the precise effect of ondansetron on the PAS, therefore, we performed a systematic review and meta-analysis of randomized controlled trials to evaluate and quantify the preventive effect of ondansetron on PAS. Otherwise we also compared ondansetron with meperidine about the effect on PAS and adverse effects.

\section{Methods}

\section{Literature search and study selection}

Potentially relevant studies were identified by searching PubMed and Embase databases through July 2013 with the terms of "ondansetron" and "shivering". No limitation was applied. In addition, reference lists from identified citations and relevant reviews were manually searched for additional studies. Inclusion criteria for this meta-analysis were as follows: (1) the objects underwent a surgical operation under the neuraxial anesthesia or general anesthesia; (2) the comparison was between ondansetron and placebo or meperidine about the preventive efficacy of PAS; (3) the incidences of PAS were reported in both placebo and ondansetron groups; (4) the study design was randomized clinical trial. No minimum sample sizes were considered for inclusion of studies in the analysis. The disaccords were resolved by discussion.

\section{Data extraction and quality assessment}

Data (patient characteristics, surgical setting, anesthetic type, mean core temperature $\left({ }^{\circ} \mathrm{C}\right)$ at baseline, time of drug administration, definition of PAS, and incidence of PAS) was collected individually by two reviewers. Data was extrapolated from figures as needed. The qualities of the included studies were evaluated by the Jadad scale with the full score of five points. In addition to the primary outcome of PAS; the adverse effects were also extracted from the included studies if possible. Any dispute was resolved by discussion.

\section{Statistical analysis}

The main analysis was focused on the association between ondansetron and PAS, and subgroup analyses stratified by type of anesthesia and dosage of ondansetron were also conducted. Since three included studies [13-15] investigated the prophylactic effect of meperidine on PAS, we also compared ondansetron and meperidine on PAS, and the adverse effects were also explored when available.

Either fixed-effect model or random-effect model was used according to the heterogeneity. Heterogeneity was evaluated by $\mathrm{Q}$ statistic (a significant level of $P<0.1$ ) and $I^{2}$ statistic (greater than $50 \%$ as evidence of a significant level). A two-tailed $P$ valueless than 0.05 represents statistical significance in all tests except the specific condition where a $P$ value was declared. All statistical analyses were performed with Stata 12.0 software (StataCorp, College Station, TX, USA).

\section{Results}

114 potential studies (PubMed 17, EMBASE 97) were obtained. The detailed screening flow was shown in Figure 1. After screening the titles and abstracts, 103 studies were excluded because they were duplicates or did not provide available data. Five studies were excluded by full-text screening, of which two $[18,19]$ were duplicates, two $[20,21]$ aimed to investigate the therapeutic effect of ondansetron on PAS, the other one [22] was to determine the effect of ondansetron on threshold of shivering. Detailed characteristics of 6 included studies in this meta-analysis are presented in Table 1.

Totally 533 subjects were involved in the 6 included trials, of which 235 received ondansetron, 213 received a placebo, and 85 received meperidine. The dosage of ondansetron was either $4 \mathrm{mg}$ or $8 \mathrm{mg}$ in individual study, and meperidine was $0.4 \mathrm{mg} / \mathrm{kg}$ in all the three studies $[13,15,18]$. The trial drugs were all given before anesthesia, but one [17] at the end of the surgery.

The pooled estimate suggested that ondansetron had a potential effect on the prevention of PAS $(R R=0.43$, 95\% CI, 0.27-0.70) (Figure 2), with a moderate evidence

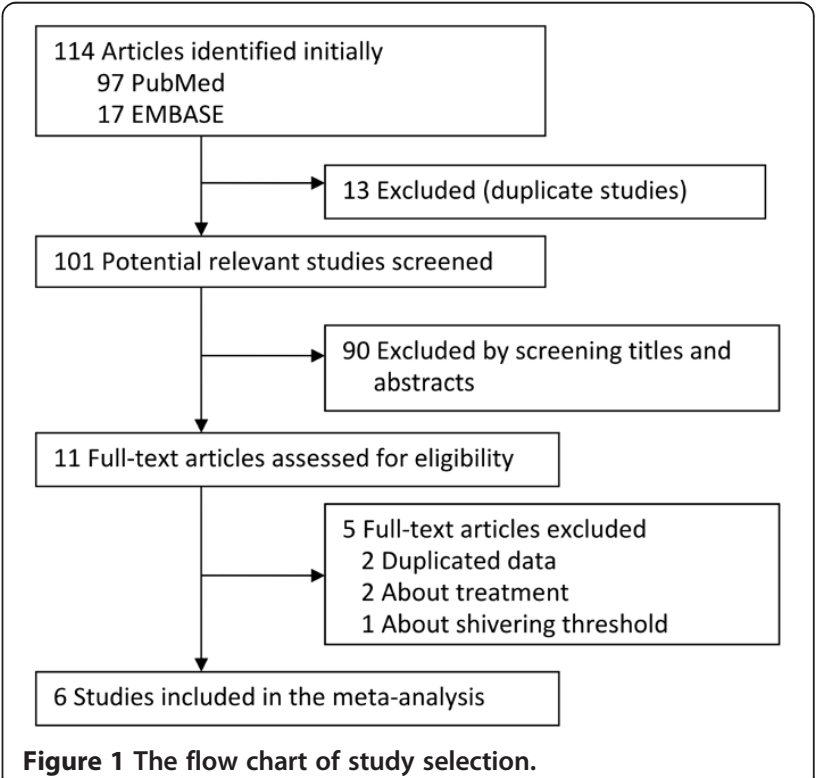


Table 1 The characteristics of the included 6 studies in this meta-analysis

\begin{tabular}{|c|c|c|c|c|c|c|c|}
\hline Study & $\begin{array}{l}\text { Study design/ } \\
\text { Jadad score }\end{array}$ & $\begin{array}{l}\text { Patient characteristics; } \\
\text { surgical setting }\end{array}$ & $\begin{array}{l}\text { Type of } \\
\text { anesthesia }\end{array}$ & $\begin{array}{l}\text { Comparisons } \\
\text { (no. patients) }\end{array}$ & $\begin{array}{l}\text { Mean } \\
\text { temperature } \\
\left({ }^{\circ} \mathrm{C}\right) \text { at baseline }\end{array}$ & $\begin{array}{l}\text { Time of } \\
\text { administration }\end{array}$ & Definition of PAS \\
\hline \multirow[t]{3}{*}{$\begin{array}{l}\text { Powell } \\
\text { et al. [16] }\end{array}$} & \multirow{3}{*}{$\begin{array}{l}\text { Randomized, placebo- } \\
\text { controlled, double- } \\
\text { blinded/ } 5\end{array}$} & \multirow{3}{*}{$\begin{array}{l}18-60 \text { yr, ASA: I - II; } \\
\text { orthopedic, general, } \\
\text { or urological surgery }\end{array}$} & \multirow[t]{3}{*}{ General } & $\begin{array}{l}\text { Ondansetron } \\
\text { IV } 4 \text { mg (27) }\end{array}$ & 36.9 & \multirow{3}{*}{$\begin{array}{l}3-5 \text { min before } \\
\text { the induction of } \\
\text { anesthesia }\end{array}$} & \multirow[t]{3}{*}{$\begin{array}{l}\text { Readily detectable fasciculations or tremors of the } \\
\text { face, trunk, or limbs of a minimum of } 15 \text {-s duration }\end{array}$} \\
\hline & & & & $\begin{array}{l}\text { Ondansetron } \\
\text { IV } 8 \mathrm{mg}(27)\end{array}$ & 36.7 & & \\
\hline & & & & Saline IV (28) & 36.7 & & \\
\hline \multirow[t]{3}{*}{$\begin{array}{l}\text { Kelsaka } \\
\text { et al. [15] }\end{array}$} & \multirow{3}{*}{$\begin{array}{l}\text { Randomized, placebo- } \\
\text { controlled, double- } \\
\text { blinded/ } 3\end{array}$} & \multirow{3}{*}{$\begin{array}{l}20-60 \text { yr, ASA: I - II; } \\
\text { elective orthopedic } \\
\text { surgery }\end{array}$} & \multirow[t]{3}{*}{ Spinal } & $\begin{array}{l}\text { Ondansetron } \\
\text { IV } 8 \mathrm{mg}(25)\end{array}$ & 36.9 & \multirow[t]{3}{*}{$\begin{array}{l}\text { Immediately before } \\
\text { spinal anesthesia }\end{array}$} & \multirow[t]{3}{*}{$\begin{array}{l}\text { Pectoralis, major muscles for fasciculations more } \\
\text { than } 10 \text { seconds' duration. }\end{array}$} \\
\hline & & & & $\begin{array}{l}\text { Meperidine IV } \\
0.4 \mathrm{mg} / \mathrm{kg}(25)\end{array}$ & 36.9 & & \\
\hline & & & & Saline IV (25) & 36.7 & & \\
\hline \multirow[t]{2}{*}{$\begin{array}{l}\text { Shakya } \\
\text { et al. [3] }\end{array}$} & \multirow[t]{2}{*}{$\begin{array}{l}\text { Randomized, placebo- } \\
\text { controlled/2 }\end{array}$} & \multirow{2}{*}{$\begin{array}{l}\text { Age > } 18 \text { yr, ASA: I - I; } \\
\text { elective lower } \\
\text { abdominal surgery }\end{array}$} & \multirow[t]{2}{*}{ Spinal } & $\begin{array}{l}\text { Ondansetron } \\
\text { IV } 4 \mathrm{mg}(40)\end{array}$ & 36.7 & \multirow[t]{2}{*}{$\begin{array}{l}\text { Just after the } \\
\text { intrathecal injection }\end{array}$} & \multirow{2}{*}{$\begin{array}{l}0=\text { no shivering. } 1=\text { piloerection or peripheral } \\
\text { vasoconstriction but no visible shivering. } 2=\text { muscular } \\
\text { activity in only one muscle group. } 3=\text { muscular activity } \\
\text { in more than one muscle group but not generalized. } \\
4=\text { shivering involving the whole body. }\end{array}$} \\
\hline & & & & Saline IV (40) & 36.8 & & \\
\hline \multirow[t]{3}{*}{$\begin{array}{l}\text { Entezari } \\
\text { et al. [14] }\end{array}$} & \multirow[t]{3}{*}{$\begin{array}{l}\text { Rrandomized, placebo- } \\
\text { controlled, single-blind/3 }\end{array}$} & \multirow{3}{*}{$\begin{array}{l}\text { Age > } 18 \text { yr, ASA: I - Il; } \\
\text { elective gynecological } \\
\text { surgery }\end{array}$} & \multirow[t]{3}{*}{ General } & $\begin{array}{l}\text { Ondansetron } \\
\text { IV } 4 \mathrm{mg}(30)\end{array}$ & 37.5 & \multirow[t]{3}{*}{$\begin{array}{l}2 \text { minutes before } \\
\text { inducting anesthesia }\end{array}$} & \multirow[t]{3}{*}{ Chills for at least 15 seconds } \\
\hline & & & & $\begin{array}{l}\text { Meperidine IV } \\
0.4 \mathrm{mg} / \mathrm{kg}(30)\end{array}$ & 37.4 & & \\
\hline & & & & Saline IV (30) & 37.5 & & \\
\hline \multirow[t]{3}{*}{$\begin{array}{l}\text { Abdollahi } \\
\text { et al. [13] }\end{array}$} & \multirow[t]{3}{*}{$\begin{array}{l}\text { Randomized, placebo- } \\
\text { controlled, double-blind/3 }\end{array}$} & \multirow{3}{*}{$\begin{array}{l}\text { All ages, ASA: I - III; off- } \\
\text { pump coronary artery } \\
\text { bypass graft }\end{array}$} & \multirow[t]{3}{*}{ General } & $\begin{array}{l}\text { Meperedine IV } \\
0.4 \mathrm{mg} / \mathrm{Kg}(30)\end{array}$ & NA & \multirow[t]{3}{*}{$\begin{array}{l}15 \text { minutes before the } \\
\text { end of surgery }\end{array}$} & \multirow{3}{*}{$\begin{array}{l}0=\text { Patient with no shivering. } 1=\text { whenever one of these } \\
\text { symptoms is present: peripheral vasoconstriction, peripheral } \\
\text { cyanosis without any other reason and piloerection without } \\
\text { muscle contraction. } 2=\text { Visible muscular activity that } \\
\text { involved only one muscle group. } 3=\text { Visible muscular activity } \\
\text { that involved more than one muscle group. } 4=\text { Intensive } \\
\text { muscular activity that involved the whole body. }\end{array}$} \\
\hline & & & & $\begin{array}{l}\text { Ondansetron } \\
\text { IV } 8 \text { mg (30) }\end{array}$ & NA & & \\
\hline & & & & Saline IV (30) & NA & & \\
\hline \multirow[t]{2}{*}{$\begin{array}{l}\text { Browning } \\
\text { et al. [17] }\end{array}$} & \multirow{2}{*}{$\begin{array}{l}\text { Randomized, placebo- } \\
\text { controlled, double- } \\
\text { blinded/5 }\end{array}$} & \multirow{2}{*}{$\begin{array}{l}\text { Age > } 18 \text { yr, ASA: I - Il; } \\
\text { elective cesarean } \\
\text { surgery }\end{array}$} & \multirow[t]{2}{*}{$\begin{array}{l}\text { Combined spinal } \\
\text { epidural anesthesia }\end{array}$} & $\begin{array}{l}\text { Ondansetron } \\
\text { IV } 8 \text { mg (56) }\end{array}$ & 36.6 & \multirow[t]{2}{*}{ Before anesthesia } & \multirow{2}{*}{$\begin{array}{l}0=\text { no shivering. } 1 \text { = or more of the following: piloerection, } \\
\text { peripheral vasoconstriction, peripheral cyanosis without other } \\
\text { cause but without visible muscular activity. } 2 \text { = visible } \\
\text { muscular activity confined to } 1 \text { muscle group. } 3=\text { visible } \\
\text { muscular activity in more than } 1 \text { muscle group. } 4 \text { = gross } \\
\text { muscular activity involving the entire body. }\end{array}$} \\
\hline & & & & Saline IV (60) & 36.8 & & \\
\hline
\end{tabular}




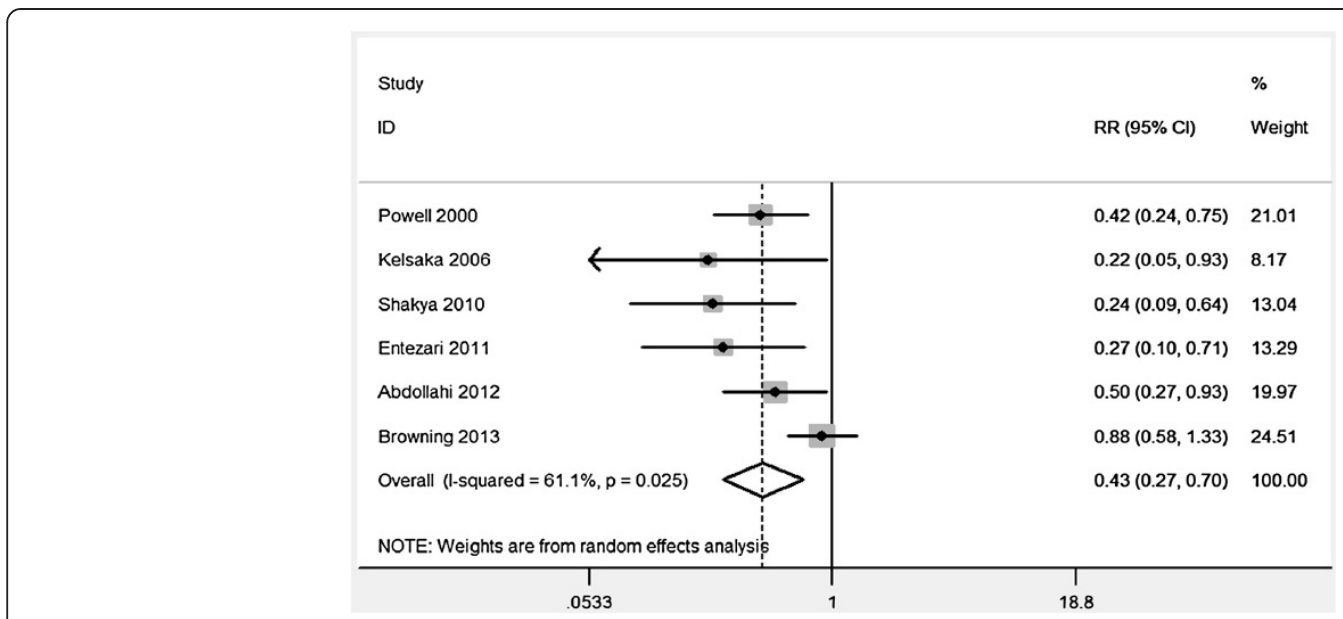

Figure 2 The pooled estimate of the 6 included studies by random effect model.

of heterogeneity $\left(I^{2}=61.1 \%, P=0.025\right)$. Results of subgroup analyses were showing in Table 2 , and all demonstrated that ondansetron was associated with a significant reduction of PAS risk.

Additionally, the adverse effect and comparison with meperidine of ondansetron were analyzed with a limited test power. Compared to placebo, no significant association of ondansetron with bradycardia was found $(R R=2.00,95 \%$, 0.38-10.64). Significant differences of ondansetron were also not observed in PAS ( $\mathrm{RR}=0.68,95 \% \mathrm{CI}, 0.39-1.19$ ) and bradycardia ( $\mathrm{RR}=2.0,95 \% \mathrm{CI}, 0.38-10.64)$ by comparison with meperidine (Figures 3 and 4).

\section{Discussion}

According to our findings, compared with placebo, ondansetron could reduce the prevalence of PAS from $49.3 \%$ (placebo) to $23.4 \%$ without increased risk of bradycardia. However, No superiority was observed in ondansetron over meperidine on the effect of antishivering and incidence of bradycardia.

Serotonin system plays an important role in the thermoregulation. The mechanisms of ondansetron on PAS may be related to a central mechanism of the inhibition of

Table 2 Results of subgroup analysis by dosage of ondansetron and anesthetic techniques

\begin{tabular}{llllll}
\hline Group & $\begin{array}{l}\text { No. of } \\
\text { studies }\end{array}$ & Relative risk & $\mathbf{I}^{\mathbf{2}}$ & $\mathbf{P}_{\text {heterogeneity }}$ & $\begin{array}{l}\text { Effect } \\
\text { model }\end{array}$ \\
\hline Dosage & & & & & \\
\hline $4 \mathrm{mg}$ & 3 & $0.36(0.22,0.58)$ & 40.7 & 0.185 & Fixed \\
$8 \mathrm{mg}$ & 3 & $0.47(0.25,0.90)$ & 66.0 & 0.032 & Random \\
Anesthetic technique & & & & \\
General 3 & $0.40(0.27,0.60)$ & 0 & 0.559 & Fixed \\
Spinal & 2 & $0.23(0.10,0.52)$ & 0 & 0.949 & Fixed \\
\hline
\end{tabular}

5-HT reuptake on the preoptic anterior hypothalamic region [15]. It was proven that 5-HT3 agonist could induce hyperthermia, and its antagonist could lead to hypothermia [23,24]. However, in healthy volunteers, the core-temperature thresholds triggering shivering did not change under comparison with placebo [22]. Several studies $[15,16,25]$ have proven that core-to-peripheral redistribution of body temperature after the general anesthetics is characterized by 1 decrease in the core temperature at the first 20 to 30 minutes, and this alteration kept similar in ondansetron group $[15,16]$. The evidences above suggested that the effect of ondansetron on the prevention of PAS is irrelevant to the core hypothermia. On the contrary, Kelsaka et al. [15] found that the core temperature was preserved in ondansetron group rather than placebo, but no one shared the same idea with them. So there is little evidence supporting preserving the temperature to be another antishivering mechanism.

Shivering differs from general anesthesia to neuraxial anesthesia. General anesthesia could impair the central thermoregulation, while neuraxial anesthesia impairs both central and peripheral thermoregulation, by enlarging interthreshold range via raising the sweating threshold and decreasing the vasoconstriction and shivering thresholds [26]. The core temperature decrease will be in a plateau after 3-4 $\mathrm{h}$ in general anesthesia but no plateau appears in the neuraxial anesthesia, because the vasoconstriction will be evoked when the core temperature triggers the reset vasoconstriction threshold in general anesthesia but not neuraxial anesthesia [2]. Thus, more heat will be lost, and more incidences will occur in neuraxial anesthesia. However, in our analysis, there was no difference in the risks of PAS between general and neuraxial anesthesia. It might be explained by short duration of the operation, and limited sample sizes, different heat preservation measures after operation. 


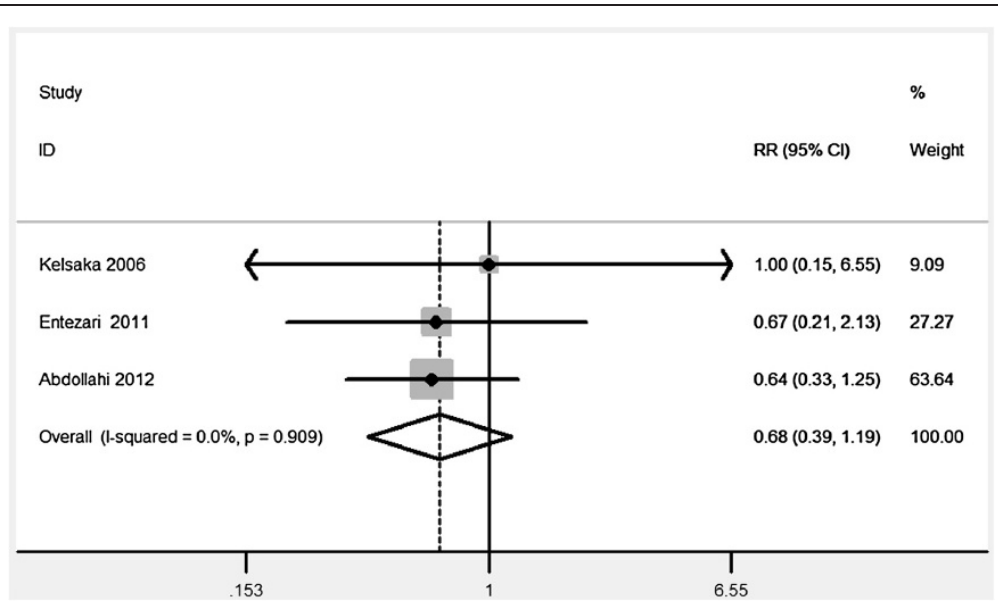

Figure 3 The antishivering effect of ondansetron comparing with meperdine.

As for dose-dependent effect of ondansetron on shivering, Powell et al. [16] found that ondansetron was associated with a dose-dependent reduction in shivering, while the effect was not observed in pooled effect. As we can see the incidence of shivering was $10 \%$ in people weighed about $52 \mathrm{~kg}$ with low-dose ondansetron $(4 \mathrm{mg})$ used [15], but Powell et al. [16] found the incidence was $8 \%$ in people weighed about $76 \mathrm{~kg}$ with high-dose ondansetron $(8 \mathrm{mg})$. So we presume the various weights of the subjects might mask the dose-dependent effect. When compared to other drugs, ondansetron is absent from the hemodynamic effect in the treatment and prevention of PAS [15,26,27], which contributes much to its safety. Thus, the result that no difference exists in bradycardia between ondansetron and placebo is acceptable despite a limited sample. Additionally, two fresh studies demonstrated ondansetron is safe for pregnant women and fetus $[28,29]$. Apart from the primary outcome of
PAS and side effect of bradycardia, other side effects were also mentioned but were not appropriate for quantitative analysis, among which none indicated a significant risk of convulsion, myoclonus, rush, pruritus, headache, pain, hypotension, sedation, nausea or vomiting.

Meperidine has a therapeutic effect on PAS, and its mechanism is likely to be associated with activation of $\mathrm{K}$ receptor [30-32]. In our meta-analysis, we compared the effect of meperidine and ondansetron on the prevention of PAS, no significant superiority was found in ondansetron. While taking the adverse effects into consideration, accumulating studies show that meperidine could increase the incidence of nausea and vomiting $[30,31]$ and induce respiratory depression [16]. Like ondansetron, meperidine at dose of $0.4 \mathrm{mg} / \mathrm{kg}$ for treatment of PAS rarely causes cardiovascular effects, which were also poorly confirmed by our combined estimate with small sample.

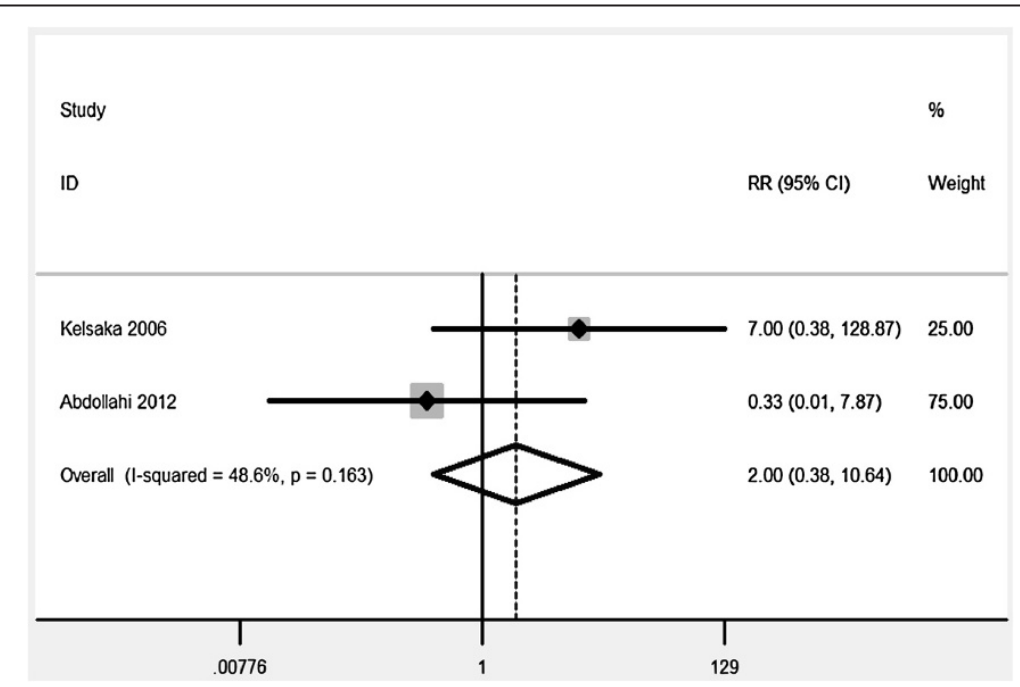

Figure 4 The side effects of bradycardia of ondansetron by comparing with meperdine. 
Many drugs aimed at the treatment and prophylactic of PAS have been found. Physostigmine inhibits PAS through cholinergic system, but it would also cause nausea and vomiting, increased heart rate and blood pressure [33]. Tramadol, which could inhibit 5HT-uptake and increase its release, reduces PAS after general anesthesia [34]. In contrast to ondansetron, it could depress the thresholds of sweating, vasoconstriction and shivering [35]. Doxapram, used as a stimulant in respiratory failure, had been proven to be effective on PAS, but accompanied with distinct side effect on hemodynamics [14]. From our analysis and the comparisons, ondansetron exhibited a high safety profile.

Study by Browning et al. [17], which found ondansetron could not reduce the incidence of shivering, contributed to the heterogeneity as identified by forest plots and sensitive analysis. The subgroup analysis also confirmed the source of the heterogeneity was from the study (data not show). Many factors could be related to the heterogeneity, the most important one is the definition of PAS the author used [36]. Otherwise, the subjects involved in this study were all female, pregnant, and young, and the anesthetic technique was combined spinal epidural anesthesia, which differed from the others. When omitting this study, homogeneity appeared and the pooled estimate became more significant with a narrower confidence interval.

To our knowledge, this is the first meta-analysis to explore the prophylactic effect of ondansetron on PAS. Additionally, the original studies included in our metaanalysis are all randomized, double-blinded and placebocontrolled trials except one [3] without the mention of blind, and all take PAS as primary outcome. Besides, the negative association between ondansetron and the PAS remained robust and significant in both subgroup and sensitive analyses. Otherwise, we also compared ondansetron with meperidine on the effect of PAS. Moreover, the side effects and dose-dependent effect was also explored.

There are some potential limitations should be considered. Firstly, the test power, to some extent, is limited as confined by the sample size. The individual study in this meta-analysis has a relatively small sample with only one study [17] more than 100 subjects. Secondly, the definitions of PAS vary from each other. Three studies $[3,13,17]$ used a graded scale to evaluate the severity of shivering, and others [14-16] defined PAS as some muscles shivering for minimum 10 or 15 seconds. Thirdly, many included studies only presented data about PAS but not simultaneous side effects (nausea and vomiting, bradycardia, hypertension etc.). And only three studies compared ondansetron with other antishivering drugs, (meperidine, ketamine), we, therefore, could not give a comprehensive evaluation of ondansetron. Finally, dosages of ondansetron were not standard; either $4 \mathrm{mg}$ or $8 \mathrm{mg}$ was administrated in the individual study.

Some directions for future research should be drawn out from current meta-analysis. The adequate sample, comprehensive side effects should be considered in future research, and the effects of various dosage of ondansetron, anesthetic technique and surgical setting on PAS should also be explored. Furthermore, studies aimed to compare ondansetron and other drugs should be conducted to evaluate the clinical and economic efficacy of ondansetron. Finally, the definition of PAS should be standardized.

\section{Conclusions}

Current meta-analysis demonstrated that ondansetron has a preventive effect on PAS without a paralleled side effect of bradycardia.

\section{Competing interests}

The authors declare that they have no competing interests.

\section{Authors' contributions}

$\mathrm{HTT}$ and GZS conceived the study, participated in the design, collected the data, performed statistical analyses, and drafted the manuscript. HTT, GZS

and HWY participated in the design, collected the data, and helped to draft the manuscript. JHM, KH and SRL helped to perform statistical analyses and to revise it critically for important intellectual content. All authors read and approved the final manuscript.

\section{Author details}

${ }^{1}$ The First College of Clinical Medicine, the First Affiliated Hospital of Chongqing Medical University, Chongqing, China. ${ }^{2}$ Department of Pharmacy, Jinan Central Hospital, Jinan 250013, Shandong, China.

Received: 10 October 2013 Accepted: 25 February 2014

Published: 3 March 2014

\section{Reference}

1. Alfonsi P: Postanaesthetic shivering. Epidemiology, pathophysiology and approaches to prevention and management. Minerva Anestesiol 2003, 69:438-442.

2. Kurz A: Physiology of thermoregulation. Best Pract Res Clin Anaesthesiol 2008, 22:627-644.

3. Shakya S, Chaturvedi A, Sah BP: Prophylactic low dose ketamine and ondansetron for prevention of shivering during spinal anaesthesia. J Anaesthesiol Clin Pharmacol 2010, 26:465-469.

4. Sajedi P, Yaraghi A, Moseli HA: Efficacy of granisetron in preventing postanesthetic shivering. Acta Anaesthesiol Taiwan 2008, 46:166-170.

5. Crowley LJ, Buggy DJ: Shivering and neuraxial anesthesia. Reg Anesth Pain Med 2008, 33:241-252.

6. Glosten B, Hynson J, Sessler DI, McGuire J: Preanesthetic skin-surface warming reduces redistribution hypothermia caused by epidural block. Anesth Analg 1993, 77:488-493.

7. Ponte J, Collett BJ, Walmsley A: Anaesthetic temperature and shivering in epidural anaesthesia. Acta Anaesthesio/ Scand 1986, 30:584-587.

8. Shehabi Y, Gatt S, Buckman T, Isert P: Effect of adrenaline, fentanyl and warming of injectate on shivering following extradural analgesia in labour. Anaesth Intensive Care 1990, 18:31-37.

9. Kranke P, Eberhart LH, Roewer N, Tramer MR: Postoperative shivering in children: a review on pharmacologic prevention and treatment. Paediatr Drugs 2003, 5:373-383.

10. Joris J, Banache M, Bonnet F, Sessler DI, Lamy M: Clonidine and ketanserin both are effective treatment for postanesthetic shivering. Anesthesiology 1993, 79:532-539.

11. Dawson NJ, Malcolm JL: Initiation and inhibition of shivering in the rat: interaction between peripheral and central factors. Clin Exp Pharmacol Physiol 1982, 9:89-93.

12. Feldberg W, Myers RD: A new concept of temperature regulation by amines in the hypothalamus. Nature 1963, 200:1325.

13. Abdollahi MH, Forouzannia SK, Bagherinasab M, Barzegar K, Fekri A, Sarebanhassanabadi $M$, Entezari $A$ : The effect of ondansetron and meperedin on preventing shivering after off-pump coronary artery bypass graft. Acta Med Iran 2012, 50:395-398. 
14. Asl ME, Isazadefar K, Mohammadian A, Khoshbaten M: Ondansetron and meperidine prevent postoperative shivering after general anesthesia. Middle East J Anesthesiol 2011, 21:67-70

15. Kelsaka E, Baris S, Karakaya D, Sarihasan B: Comparison of ondansetron and meperidine for prevention of shivering in patients undergoing spinal anesthesia. Reg Anesth Pain Med 2006, 31:40-45.

16. Powell RM, Buggy DJ: Ondansetron given before induction of anesthesia reduces shivering after general anesthesia. Anesth Analg 2000 90:1423-1427

17. Browning RM, Fellingham WH, O'Loughlin EJ, Brown NA, Paech MJ: Prophylactic ondansetron does not prevent shivering or decrease shivering severity during cesarean delivery under combined spinal epidural anesthesia: a randomized trial. Reg Anesth Pain Med 2013, 38:39-43.

18. Asl Entezari M, Isazadehfar K, Akhavanakbari G, Khoshbaten M: The effect of ondansetron in prevention of postoperative shivering after general anesthesia in gynecological surgery. Iranian Red Crescent Med J 2012, 14:316-317

19. Chaturvedi A, Shakya BM, Sah BP, Upreti D: Prophylactic low dose ketamine \& ondansetron for preventing shivering during spinal anaesthesia. Reg Anesth Pain Med 2010, 35:E76.

20. Joshi SS, Adit A, Arun G, Shidhaye RV: Comparison of intravenous butorphanol, ondansetron and tramadol for control of shivering during regional anesthesia: A prospective, randomized double-blind study. Anaesth Pain Intensive Care 2013, 17:33-39.

21. Kyokong O, Tamdee D, Charuluxananan S: Comparison of the efficacy of nalbuphine, tramadol, ondansetron and placebo in the treatment of postanesthetic shivering after spinal anesthesia for cesarean delivery. Asian Biomed 2007, 1:189.

22. Komatsu R, Orhan-Sungur M, In J, Podranski T, Bouillon T, Lauber R, Rohrbach S, Sessler D: Ondansetron does not reduce the shivering threshold in healthy volunteers. Br J Anaesth 2006, 96:732-737.

23. Kandasamy SB: Effect of ondansetron and ICS 205-930 on radiationinduced hypothermia in rats. Radiat Res 1997, 147:741-746.

24. Mazzola-Pomietto P, Aulakh CS, Murphy DL: Temperature, food intake, and locomotor activity effects of a 5-HT3 receptor agonist and two 5-HT3 receptor antagonists in rats. Psychopharmacology (Berl) 1995, 121:488-493.

25. Matsukawa T, Sessler DI, Sessler AM, Schroeder M, Ozaki M, Kurz A, Cheng C: Heat flow and distribution during induction of general anesthesia. Anesthesiology 1995, 82:662-673.

26. Lenhardt R: The effect of anesthesia on body temperature control. Front Biosci (Schol Ed) 2010, 2:1145-1154.

27. Diemunsch P, Conseiller C, Clyti N, Mamet JP: Ondansetron compared with metoclopramide in the treatment of established postoperative nausea and vomiting. The French Ondansetron Study Group. Br J Anaesth 1997 79:322-326.

28. Ondansetron looks safe in pregnancy, so far. BMJ 2013, 346:f1387. doi:http://dx.doi.org/10.1136/bmj.f1387.

29. Pasternak B, Svanstrom $H$, Hviid A: Ondansetron in pregnancy and risk of adverse fetal outcomes. N Engl J Med 2013, 368:814-823.

30. Anaraki AN, Mirzaei K: The Effect of Different Intrathecal Doses of Meperidine on Shivering during Delivery Under Spinal Anesthesia. Int J Prev Med 2012, 3:706-712.

31. Dabir S, Jahandideh M, Abbasinazari M, Kouzekanani H, Parsa T, Radpay B: The efficacy of a single dose of pethidine, fentanyl and morphine in treating postanesthesia shivering. Pak J Pharm Sci 2011, 24:513-517.

32. Park SM, Mangat HS, Berger K, Rosengart AJ: Efficacy spectrum of antishivering medications: meta-analysis of randomized controlled trials. Crit Care Med 2012, 40:3070-3082

33. Horn EP, Standl T, Sessler DI, von Knobelsdorff G, Buchs C, Schulte am Esch J: Physostigmine prevents postanesthetic shivering as does meperidine or clonidine. Anesthesiology 1998, 88:108-113.

34. de Witte J, Deloof T, de Veylder J, Housmans PR: Tramadol in the treatment of postanesthetic shivering. Acta Anaesthesiol Scand 1997, 41:506-510
35. De Witte JL, Kim JS, Sessler DI, Bastanmehr H, Bjorksten AR: Tramadol reduces the sweating, vasoconstriction, and shivering thresholds. Anesth Analg 1998, 87:173-179.

36. Gu WJ, Liu JC: Ondansetron and shivering during cesarean delivery under combined spinal epidural anesthesia: a live issue. Reg Anesth Pain Med 2013, 38:252.

doi:10.1186/1471-2253-14-12

Cite this article as: Tie et al:: Efficacy and safety of ondansetron in preventing postanesthesia shivering: a meta-analysis of randomized controlled trials. BMC Anesthesiology 2014 14:12.

\section{Submit your next manuscript to BioMed Central and take full advantage of:}

- Convenient online submission

- Thorough peer review

- No space constraints or color figure charges

- Immediate publication on acceptance

- Inclusion in PubMed, CAS, Scopus and Google Scholar

- Research which is freely available for redistribution

Submit your manuscript at www.biomedcentral.com/submit
C BioMed Central 